\title{
Influence of Plasma Nitriding with a Nitrogen Rich Gas Composition on the Reciprocating Sliding Wear of a DIN 18MnCrSiMo6-4 Steel
}

\author{
Rafael Luciano Dalcin ${ }^{a *}$ (D), Alexandre da Silva Rocha ${ }^{a}$ (D), Victor Velho de Castro ${ }^{b}$ (D), \\ Leonardo Fonseca Oliveira ${ }^{\text {(D) , Julio Cesar Klein das Neves }}{ }^{c}$ (D), Carlos Henrique da Silvac (D), \\ Célia de Fraga Malfatti ${ }^{b}$

\begin{abstract}
${ }^{a}$ Universidade Federal do Rio Grande do Sul, Laboratório de Transformação Mecânica, Porto Alegre, RS, Brasil

${ }^{b}$ Universidade Federal do Rio Grande do Sul, Laboratório de Pesquisa em Corrosão, Porto Alegre, RS, Brasil

'Universidade Tecnológica Federal do Paraná, Laboratório de Superfícies e Contato, Curitiba, PR, Brasil
\end{abstract}

Received: December 26, 2020; Revised: April 14, 2021; Accepted: April 28, 2021

\begin{abstract}
In this study, the sliding wear of a DIN 18MnCrSiMo6-4 continuous cooling bainitic steel plasma nitrided with a nitrogen rich gas composition was investigated. To evaluate the influence of processing time and temperature on mechanical and microstructural characteristics of nitrided layer, the samples were nitrided at $400,450,500$ and $550{ }^{\circ} \mathrm{C}$ for 3,6 and $9 \mathrm{~h}$. The produced nitrided layers were characterized concerning the microstructure, phase composition, microhardness and surface roughness. The samples were tested by ball-on-flat reciprocating dry sliding for friction coefficient and wear analysis. The tests were stopped after a given damage criteria involving the rapid growth of the friction coefficients and wear. The correlation of the different treatment parameters and resulting case depths and surface hardness with sliding distance at the time of microcracks formation or delamination of the surface layer was evaluated statistically by the analysis of variance (ANOVA). The plasma nitrided samples at $550{ }^{\circ} \mathrm{C}$ showed better wear performances in the ball-on-flat tests than the other groups investigated, since these samples have a thicker compound layer and diffusion zone higher than the other conditions investigated. In general, the beginning wear is slower because of the hardest region of the compound layer.
\end{abstract}

Keywords: Plasma Nitriding, Continuous Cooling Bainitic Steel, Wear Resistance, Reciprocating Dry Sliding.

\section{Introduction}

Continuous cooling bainitic steel has an increasing use in industrial processes owing to its excellent outstanding combination of yield strength and toughness ${ }^{1-3}$, the possibility to reduce the process chain and reduced energy consumption ${ }^{4-7}$. Although their surface properties are acceptable for many purposes $^{8-11}$, surface hardness and wear resistance are insufficient for some highly loaded automotive components as gears for example. Therefore, the improvement of surface properties is essential. Several surface treatments have been considered for advanced high strength steels for automotive applications $^{12-14}$.

The plasma nitriding process can be used to develop outstanding surface properties while carrying treatments using relatively low treatment temperatures ${ }^{15,16}$, thus representing a reliable alternative to conventional thermal and thermochemical treatments. Since long nitriding times can have a detrimental effect on the mechanical properties of steel, the treatment temperature should be carefully selected

*e-mail: rafael.dalcin@ufrgs.br to avoid overheating of the steel itself and to preserve the bainitic microstructure of these steels, as well as softening of the plasma nitrided layer due to the excess aging of nitrides ${ }^{15,17}$. The microstructure of the plasma nitrided layer must be well controlled to achieve the desired increase in surface hardness and provide significant improvements in wear resistance $\mathrm{e}^{18,19}$.

This study is a sequence of a previous work about plasma nitriding of continuous cooling bainitic steel ${ }^{15}$. The previous investigations showed excellent results with respect to case depth, surface hardness and compressive residual stresses in the diffusion zone. Despite the variety and particularities of investigations concerning the wear resistance of plasma nitrided steels ${ }^{20-23}$, the influence of plasma nitriding on the reciprocating dry sliding wear of continuous cooling bainitic steels is relatively scarce. The main objective of this work is to improve the surface properties of DIN 18MnCrSiMo6-4 continuous cooling bainitic steel by plasma nitriding, aiming to increase surface hardness and optimize its wear resistance in reciprocating sliding. In order to study the influence of 
plasma nitriding with a nitrogen rich gas composition on the reciprocating sliding wear of a DIN 18MnCrSiMo6-4 continuous cooling bainitic steel, a systematic variation of temperature and time parameters has been carried out. The major contribution of the work is to attempt, through statistical methods, to establish correlations between performance parameters (wear, layer thickness, hardness) and temperature and time employed to produce the modified surfaces.

\section{Materials and Methods}

The steel to be plasma nitrided was a DIN 18MnCrSiMo6-4 steel $(0.19 \%$ C, $1.16 \% \mathrm{Si}, 1.35 \% \mathrm{Mn}, 1.14 \% \mathrm{Cr}, 0.26 \%$ Mo and $0.06 \% \mathrm{Ni}$ ) which is a continuous cooling bainitic steel. The material's microstructure is composed of pro-eutectoid ferrite and granular bainite after hot rolling ${ }^{7,15}$. In the case of continuous cooling bainitic steels there is no annealing (tempering) treatment applied as the microstructure was obtained directly after hot rolling and controlled cooling. Prior to the surface treatments, samples flat surfaces were ground with silicon carbide grinding paper in a sequence with increasing grit sizes (\#100, \#220, \#320, \#400, \#600, $\# 1200$ ) and then polished with $3 \mu \mathrm{m}$ diamond paste, in order to obtain low roughness, and almost no plastic deformation.

The surface treatment was carried out in a plasma nitriding furnace equipped with a DC power supply which was developed by the Technology Center and Metallurgy Department of Federal University of Rio Grande do Sul. The samples were degreased and cleaned with acetone in an ultrasonic bath before being placed into the plasma nitriding furnace. The sputtering was performed for $15 \mathrm{~min}$, using pure hydrogen with a flow of $140 \mathrm{sccm}$, and in the heating step until reaching the treatment temperature, a gas mixture composed of argon and hydrogen was used, with $150 \mathrm{sccm}$ of argon and $140 \mathrm{sccm}$ of hydrogen $\left(\mathrm{H}_{2}\right)$. For the plasma nitriding process, a gas mixture composed of 76 vol. $\%$ nitrogen $\left(\mathrm{N}_{2}\right)$ and 24 vol. $\% \mathrm{H}_{2}$ was used. The treatment parameters are shown in Table 1.

In this work is studied the influence of processing time $(3,6$ and $9 \mathrm{~h})$ and temperature $\left(400,450,500\right.$ and $\left.550^{\circ} \mathrm{C}\right)$ on mechanical and microstructural characteristics of plasma nitrided layer. The temperature range based on common plasma nitriding temperatures for low alloyed steels, from
400 to $550{ }^{\circ} \mathrm{C}$, to evaluate the maximum temperature that could be used to accelerate the layer growth without causing a decrease in core hardness ${ }^{15}$. The nitrogen rich gas composition ( $76 \mathrm{vol} \% \mathrm{~N}_{2}$ ) is commonly used in gas nitriding, as it provides formation of higher layer depths. Therefore, in this work we firstly choose to employ this fixed composition and vary temperature and time. The current density was calculated by dividing the measured current by the total area covered by the plasma sheath. The current density cannot be directly controlled, as we did not use an auxiliary heating system. The current density is dependent on the desired treatment temperature and depends on the gas mixture being used, and on the heat exchange in the furnace.

For the microstructural analysis of the plasma nitrided layers, samples were carefully cut perpendicular to the upper nitrided face in a precision diamond blade cutting machine. After hot pressing mounting in bakelite, the crosssections were ground with silicon carbide grinding papers in a sequence with increasing grit sizes (\#100,\#220, \#320, $\# 400, \# 600, \# 1200$ ) and polished with a diamond paste of $3 \mu \mathrm{m}$ particle size. A Nital 3\% solution was used to etch the samples revealing the microstructure of the nitrided layers. The cross-sectional microstructural images were obtained by an Olympus metallurgical microscope (BX51M model). The compound layer thickness was measured using the Image- $J$ software.

$\mathrm{X}$-ray phase analysis was carried out using a XRD $M$ - Research Edition diffractometer (GE Seifert Charon model) equipped with a Meteor $1 D$ fast line position sensitive detector. Phase analysis was performed on samples surface in the Bragg-Brentano geometry $(\theta-2 \theta)$ with $\mathrm{Cr}-\mathrm{K} \alpha$ $(\lambda=2.2897 \AA)$ radiation. Diffraction lines were recorded in the range of $2 \theta$ from $55^{\circ}$ to $80^{\circ}$, with a step size of $0.01^{\circ}$ and a scan time of $200 \mathrm{~s}$ per step. The phases present in the non-nitrided and in the plasma nitrided material were determined by comparative analysis between the standards contained in the crystallographic information files (CIFs) from the Crystallography Open Database ${ }^{24}$ and the Inorganic Crystal Structures Database $e^{25}$ by analysis using the Profex$B G M N$ software ${ }^{26}$.

Vickers microhardness tests were applied to the plasma nitrided samples for determination of the surface hardness and Vickers microhardness profiles of the cross-sections.

Table 1. Parameters used for plasma nitriding of samples using a gas composition of $76 \mathrm{vol} . \% \mathrm{~N}_{2}$.

\begin{tabular}{|c|c|c|c|c|}
\hline Temperature & Nitriding time & Gas mixtures & Current density & Pressure \\
\hline$\left({ }^{\circ} \mathrm{C}\right)$ & (h) & $\left(\right.$ vol. $\% \mathrm{~N}_{2}$ in $\left.\mathrm{H}_{2}\right)$ & $\left(\mathrm{mA} / \mathrm{cm}^{2}\right)$ & $(\mathrm{Pa})$ \\
\hline \multirow{3}{*}{$400 \pm 2$} & 3 & \multirow{3}{*}{76 vol. $\% \mathrm{~N}_{2}$ in 24 vol. $\% \mathrm{H}_{2}$} & \multirow{3}{*}{$2.0 \pm 0.06$} & \multirow{3}{*}{$300 \pm 3$} \\
\hline & 6 & & & \\
\hline & 9 & & & \\
\hline \multirow{3}{*}{$450 \pm 2$} & 3 & \multirow{3}{*}{76 vol. $\% \mathrm{~N}_{2}$ in 24 vol. $\% \mathrm{H}_{2}$} & \multirow{3}{*}{$2.2 \pm 0.06$} & \multirow{3}{*}{$300 \pm 3$} \\
\hline & 6 & & & \\
\hline & 9 & & & \\
\hline \multirow{3}{*}{$500 \pm 2$} & 3 & \multirow{3}{*}{76 vol. $\% \mathrm{~N}_{2}$ in 24 vol. $\% \mathrm{H}_{2}$} & \multirow{3}{*}{$2.4 \pm 0.10$} & \multirow{3}{*}{$300 \pm 3$} \\
\hline & 6 & & & \\
\hline & 9 & & & \\
\hline \multirow{3}{*}{$550 \pm 2$} & 3 & \multirow{3}{*}{76 vol. $\% \mathrm{~N}_{2}$ in 24 vol. $\% \mathrm{H}_{2}$} & \multirow{3}{*}{$2.9 \pm 0.06$} & \multirow{3}{*}{$300 \pm 3$} \\
\hline & 6 & & & \\
\hline & 9 & & & \\
\hline
\end{tabular}


In the tests, an Insize micro hardness tester (ISH-TDV 1000 model) was used. Five microhardness profiles per sample were constructed, using a load of $100 \mathrm{gf}$ with a dwell time of $10 \mathrm{~s}^{27}$. The case depth (compound layer + diffusion zone) was conventionally determined by the distance from the surface where the core hardness is exceeded in $50 \mathrm{HV}$. The determination of the case depth was carried out based on the microhardness profiles and following the recommendations established in DIN $50190^{28}$.

The roughness parameters $\left(\mathrm{R}_{\mathrm{a}}\right.$ and $\left.\mathrm{R}_{\mathrm{z}}\right)$ were measured with a Mitutoyo contact profilometer ( $S J-210$ model) equipped with an $8 \mu \mathrm{m}$ tip radius probe, based on ISO $4287^{29}$. Due to the topographic characteristics of the samples, measurements were made using the aperiodic roughness profile configuration ${ }^{30}$. In this case, a cutoff value of $0.8 \mathrm{~mm}$ and a measurement length of $4.0 \mathrm{~mm}$ was set on the profilometer.

Wear tests were conducted using a CETR UMT (Universal Materials Tester) tribometer with a reciprocating ball-onflat configuration, according to the standard ASTM G133 $3^{31}$. Tests were performed in a room with 50 to $55 \%$ of relative humidity and the temperature at $23{ }^{\circ} \mathrm{C}$. The treated surfaces were placed in contact against a $4.76 \mathrm{~mm}$ zirconia ball $\left(1150 \mathrm{HV}_{0.1} \pm 28\right)$. The choice of a ball with a close hardness to the nitrided surface is due to the need to simulate the contact conditions with a close hardness, such as for example, the contact between the flanks of the gears, to be tested in future works. The load of $6 \mathrm{~N}$ was applied (maximum contact pressure nearly $1351 \mathrm{MPa}$ ), and the tests were conducted until the microcracks formation or the delamination of the surface layer. The applied load was selected aiming to analyze the wear resistance of the whole case (compound layer + diffusion zone), and not the specific wear resistance of the compound layer. The maximum contact pressure $\left(p_{o}\right)$ of $1351 \mathrm{MPa}$ was estimated for wear tests through the equation $\left[\mathrm{p}_{\mathrm{o}}=\left(3 . \mathrm{W} / 2 \cdot \pi \cdot \mathrm{a}^{2}\right)\right]$, being $(\mathrm{W})$ is the normal load and (a) is the radius of the contact area ${ }^{32}$. For this reason, it was chosen to use a high contact pressure. Sliding proceeded in the reciprocating mode over a $4 \mathrm{~mm}$ track at a frequency of $4 \mathrm{~Hz}$. The surface topography and track profiles were acquired in a Bruker interferometer (Contour Elite model). The cross-sectional area was measured, using the Image- $J$ software, in three regions of each worn track.
Finally, to identify wear mechanisms, some specific analysis of the balls and wear tracks were carried out in a Zeiss scanning electron microscope (EVO MA 15 model). Interaction plots for case depth, surface hardness, and sliding distance at the time of microcracks formation or delamination of the surface layer, with nitriding temperature and time were generated. The data was then submitted to an analysis of variance, in order to evaluate the statistical significance of temperature variation and treatment time on wear, following the Tukey's-b post hoc test ${ }^{33}$ by using the statistical package program (Minitab 16). Three repetitions and a confidence level of $95 \%$ (significance level $\alpha=0.05$ ) were used.

\section{Results and Discussion}

\subsection{Microstructure, phase analysis and microhardness}

As a representative result of treatments using the gas mixture of $76 \mathrm{vol} . \% \mathrm{~N}_{2}$ and $24 \mathrm{vol} . \% \mathrm{H}_{2}$, cross-sectional microstructures of a plasma nitrided sample at $550{ }^{\circ} \mathrm{C}$ and $400{ }^{\circ} \mathrm{C}$ are shown in Figure 1a, b, respectively. The white portion on top distinguishes the compound layer, as seen at Figure 1a. For plasma nitrided samples at the lowest temperature, Figure $1 \mathrm{~b}$, the case depth is predominantly composed of the diffusion zone with a very thin compound layer (see Table 2). Under conditions where samples were plasma nitrided at temperatures higher than $400{ }^{\circ} \mathrm{C}$, effective compound layer appears in the metallography. All different nitriding conditions in the present work, besides the diffusion zone, led to the formation of compound layer. Table 2 shows the average case depth of the plasma nitrided samples for different treatment temperatures and times. In general, the use of higher temperatures and longer treatment times favored the expansion of case depth.

Previous work ${ }^{15}$ showed that all the plasma nitrided samples exhibited diffraction peaks that indicated the formation of a compound layer. Since the penetration depth of radiation decreases with $2 \theta$ angle ${ }^{34}$, the peaks of the $\varepsilon-\mathrm{Fe}_{2-3}(\mathrm{C}) \mathrm{N}$ phase, contained in the compound layer, are easily identified with smaller $2 \theta$ angles. Therefore Figure $2 \mathrm{a}-\mathrm{c}$ present the diffractograms for the $(2 \theta)$ angular interval from $55^{\circ}$ to $80^{\circ}$.

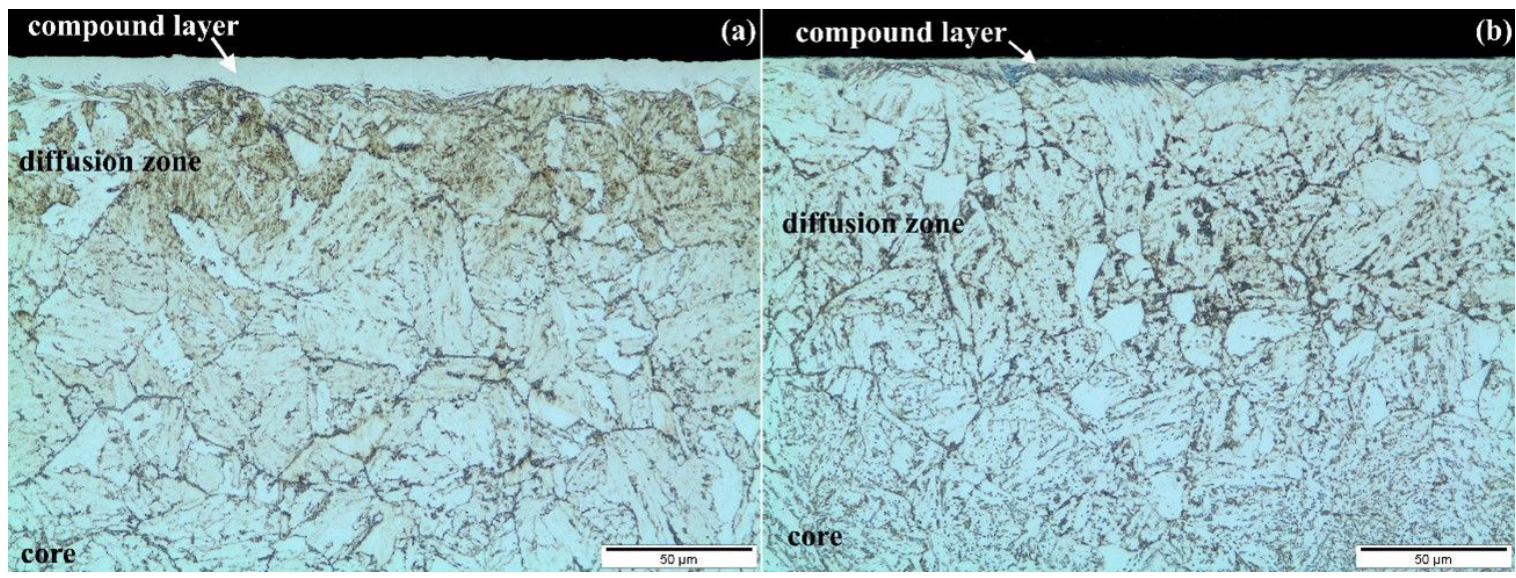

Figure 1. Optical microstructure of cross-section of plasma nitrided samples at: (a) $550{ }^{\circ} \mathrm{C}$ for $6 \mathrm{~h}$ (compound layer predominant); (b) $400{ }^{\circ} \mathrm{C}$ for $3 \mathrm{~h}$ (diffusion zone predominant). 
Table 2. Compilation of results from case depth, compound layer thickness, surface hardness and sliding distance at the time of microcracks formation or delamination of the surface layer.

\begin{tabular}{|c|c|c|c|c|}
\hline Nitriding parameters & $\begin{array}{l}\text { Case depth } \\
\quad(\mu \mathrm{m})\end{array}$ & $\begin{array}{l}\text { Compound layer } \\
\text { thickness }(\mu \mathrm{m})\end{array}$ & $\begin{array}{c}\text { Surface hardness } \\
\left(\mathrm{HV}_{0.1}\right)\end{array}$ & $\begin{array}{l}\text { Sliding distance* } \\
(\mathrm{m})\end{array}$ \\
\hline $400{ }^{\circ} \mathrm{C}-3 \mathrm{~h}$ & $67 \pm 20$ & $0.6 \pm 0.2$ & $1060 \pm 38$ & $11 \pm 2$ \\
\hline $400^{\circ} \mathrm{C}-6 \mathrm{~h}$ & $98 \pm 12$ & $1.5 \pm 0.2$ & $1051 \pm 28$ & $13 \pm 1$ \\
\hline $400^{\circ} \mathrm{C}-9 \mathrm{~h}$ & $125 \pm 21$ & $2.7 \pm 0.3$ & $1095 \pm 95$ & $18 \pm 1$ \\
\hline $450^{\circ} \mathrm{C}-3 \mathrm{~h}$ & $97 \pm 20$ & $2.6 \pm 0.3$ & $1253 \pm 56$ & $19 \pm 3$ \\
\hline $450^{\circ} \mathrm{C}-6 \mathrm{~h}$ & $131 \pm 24$ & $3.9 \pm 0.2$ & $1105 \pm 90$ & $18 \pm 2$ \\
\hline $450^{\circ} \mathrm{C}-9 \mathrm{~h}$ & $169 \pm 40$ & $4.8 \pm 0.4$ & $1101 \pm 56$ & $37 \pm 15$ \\
\hline $500^{\circ} \mathrm{C}-3 \mathrm{~h}$ & $139 \pm 30$ & $4.3 \pm 0.2$ & $1246 \pm 95$ & $21 \pm 6$ \\
\hline $500^{\circ} \mathrm{C}-6 \mathrm{~h}$ & $192 \pm 25$ & $6.7 \pm 0.3$ & $1295 \pm 108$ & $29 \pm 7$ \\
\hline $500^{\circ} \mathrm{C}-9 \mathrm{~h}$ & $245 \pm 40$ & $8.2 \pm 0.2$ & $1079 \pm 87$ & $30 \pm 8$ \\
\hline $550^{\circ} \mathrm{C}-3 \mathrm{~h}$ & $253 \pm 23$ & $7.9 \pm 0.3$ & $1195 \pm 45$ & $50 \pm 3$ \\
\hline $550^{\circ} \mathrm{C}-6 \mathrm{~h}$ & $308 \pm 24$ & $9.6 \pm 0.3$ & $1089 \pm 46$ & $58 \pm 0 * *$ \\
\hline $550^{\circ} \mathrm{C}-9 \mathrm{~h}$ & $335 \pm 15$ & $11.5 \pm 0.2$ & $1029 \pm 50$ & $58 \pm 0 * *$ \\
\hline
\end{tabular}

*Sliding distance at the time of microcracks formation or delamination of the surface layer. **Without COF's sudden growth.

Diffractograms of non-nitrided samples shows the $\alpha$-Iron peaks, Figure $2 \mathrm{a}-\mathrm{c}$, from the ferritic phases. The intensity of the peaks of the $\alpha$-Iron decreases and the retained austenite completely disappeared with the increase of the compound layer thickness, as the opposite takes place with $\varepsilon-\mathrm{Fe}_{2-3}(\mathrm{C})$ $\mathrm{N}$ and $\gamma^{\prime}-\mathrm{Fe}_{4} \mathrm{~N}$ phase peaks, because to the absorption of the radiation by the most superficial portions of the material. The $\alpha$ phase peaks of the nitrided samples are slightly shifted to the region of lower $2 \theta$ angle with respect to the non-nitrided samples. This is an information coming from the diffusion layer, as the compound layer is composed by (carbo)nitrides only ${ }^{15}$. In general, the peaks intensity related to the $\gamma^{\prime}-\mathrm{Fe}_{4} \mathrm{~N}$ and $\varepsilon-\mathrm{Fe}_{2-3}(\mathrm{C}) \mathrm{N}$ nitride phases increase with the temperature and treatment time, since compound layer thickness (Table 2) follow the increase of these parameters.

The surface hardness decreases, especially for longer treatments of 6 and $9 \mathrm{~h}$ (Table 2). The core hardness is also reduced in samples treated at $550{ }^{\circ} \mathrm{C}$, which is not observed for other treatment temperatures ${ }^{15}$. Higher plasma nitriding temperature leads to the intensification of defects formed in the compound layer, such as pores and cracks, and therefore the measure hardness value decreases. Our previous work shows that at high temperatures, there is also a competition between the hardening effect of nitriding and the hardness decrease due to the overheating of the steel matrix, so that the maximum hardening potential is not reached.

Figure 3a-c show microhardness profiles for the different plasma nitriding conditions. From the microhardness profiles, a case depth was estimated. As expected, the nitriding depth follows the behavior of a diffusion controlled process ${ }^{19,35}$. Plasma nitriding under the conditions implemented in this work could lead to hardness levels from 1029 to $1295 \mathrm{HV}_{0.1}$, and case depths up to $300 \mu \mathrm{m}$, see Table 2. Plasma nitriding leads to an increase in hardness on the surface (Table 2), for the reason it also ends up creating a less ductile region more prone to brittle fracture ${ }^{36}$. The mechanical properties of the diffusion zone influence the fracture properties of the compound layer, since the diffusion zone provides support for the surface compound layer ${ }^{15,16,36}$. Previous work ${ }^{15}$ showed that the higher nitriding temperature and time promoted an increase in the fracture toughness of the compound layer. This would also support the proposition that a harder substrate results in an increase in fracture toughness through improved mechanical support (load bearing capacity) of the compound layer by the diffusion zone.

\subsection{Roughness}

To investigate the influence of temperature and nitriding time on the surface topography, the roughness values (parameters $\mathrm{R}_{\mathrm{a}}$ and $\mathrm{R}_{\mathrm{z}}$ ) measured before and after plasma nitriding are shown in Figure $4 \mathrm{a}, \mathrm{b}$. In the cases shown in Figure $4 a, b$, the exposure time to ion bombardment ends up changing the final a lot, confirming the results reported by $^{37,38}$. It can be seen in Figure $4 a, b$ that after the plasma nitriding treatment the roughness $\left(\mathrm{R}_{\mathrm{a}}\right.$ and $\mathrm{R}_{\mathrm{z}}$ parameter) increases when compared to the polished surface prior to nitriding, and that the increased temperature and the nitriding time caused an increase in the roughness in the two parameters evaluated.

From a statistical point of view, the ANOVA reveals that the roughness was influenced by the nitriding temperature $\left(\mathrm{P}_{\text {-Value }}=0.00<\alpha=0.05\right)$ and that there was a synergistic effect between the temperature and the nitriding time $\left(\mathrm{P}_{\text {-Value }}=0.02<\alpha=0.05\right)$ on the increase in roughness, but it was not possible to determine the effect of treatment time $\left(\mathrm{P}_{\text {-Value }}=0.25>\alpha=0.05\right)$, due the standard deviation. Tukey's-b post hoc test shows that the greatest roughness was found in the plasma nitrided samples for $9 \mathrm{~h}$ at $550^{\circ} \mathrm{C}$, Figure $4 \mathrm{a}, \mathrm{b}$.

The three-dimensional topographic measurements revealed that the plasma nitrided surface morphology is modified by the nitriding parameters, confirming the previously presented roughness values. Figure 5a, b show the 3D surface representative images of plasma nitrided samples with gas mixture of 76 vol. $\% \mathrm{~N}_{2}$ and 24 vol. $\%$ $\mathrm{H}_{2}$. In general, there is an intense change in topography after nitriding. This generalized increase in roughness after nitriding can be related to the ion bombardment during plasma treatment and the formation mechanism of the nitrided layer ${ }^{37-39}$. Nevertheless, this increase in topography roughness may have contributed to the increased wear of the zirconia ball. 


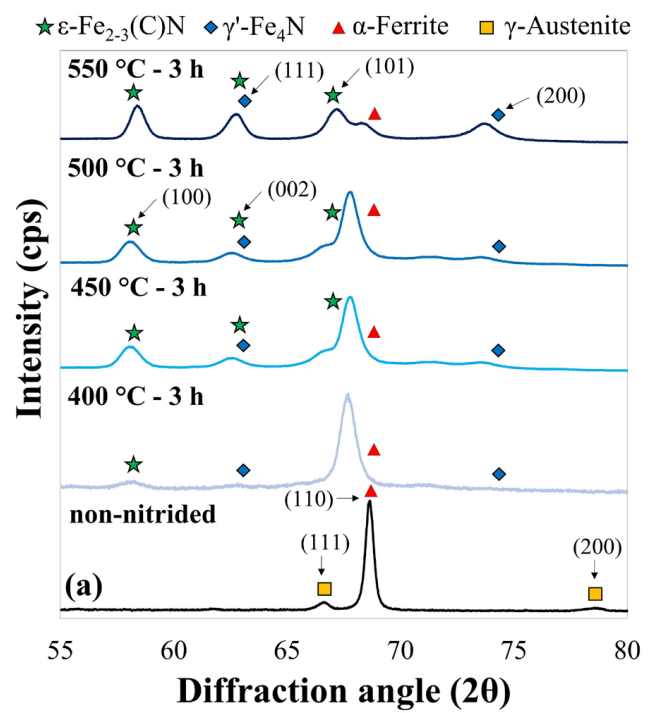

$\not \varepsilon-\mathrm{Fe}_{2-3}(\mathrm{C}) \mathrm{N} \diamond \gamma^{\prime}-\mathrm{Fe}_{4} \mathrm{~N} \quad \Delta \alpha$-Ferrite $\quad \square \gamma$-Austenite

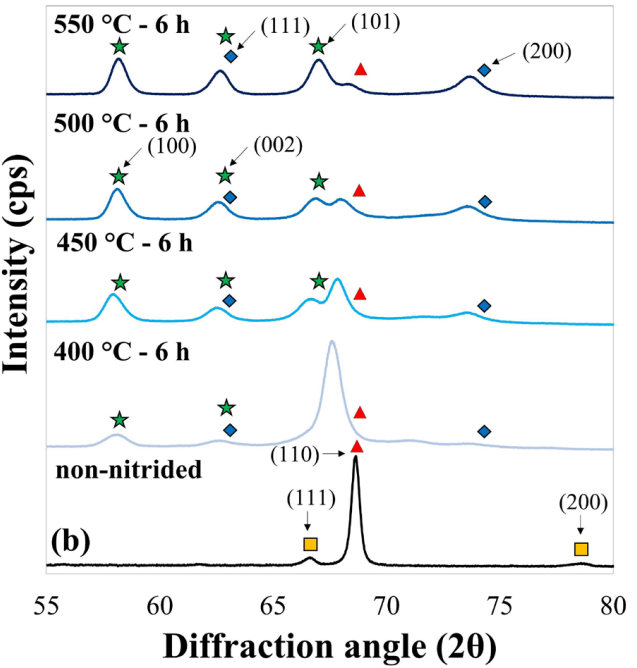

$\star \varepsilon-\mathrm{Fe}_{2-3}(\mathrm{C}) \mathrm{N} \diamond \gamma^{\prime}-\mathrm{Fe}_{4} \mathrm{~N} \quad \Delta \alpha$-Ferrite $\quad \square \gamma$-Austenite

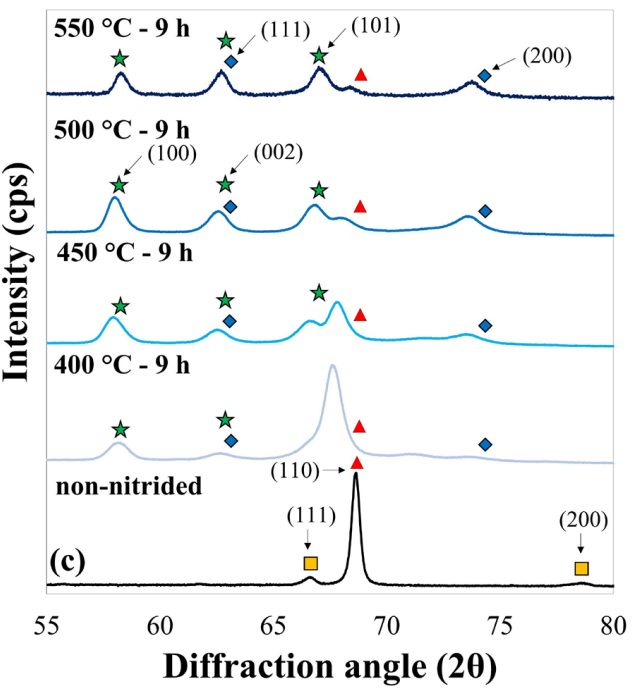

Figure 2. X-ray diffractograms of non-nitrided samples and plasma nitrided samples at $400,450,500$ and $550{ }^{\circ} \mathrm{C}$ for (a) $3 \mathrm{~h}$, (b) $6 \mathrm{~h}$ and (c) $9 \mathrm{~h}$.

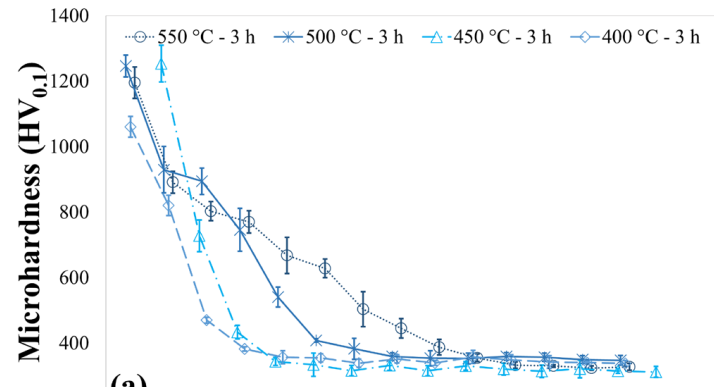

(a)

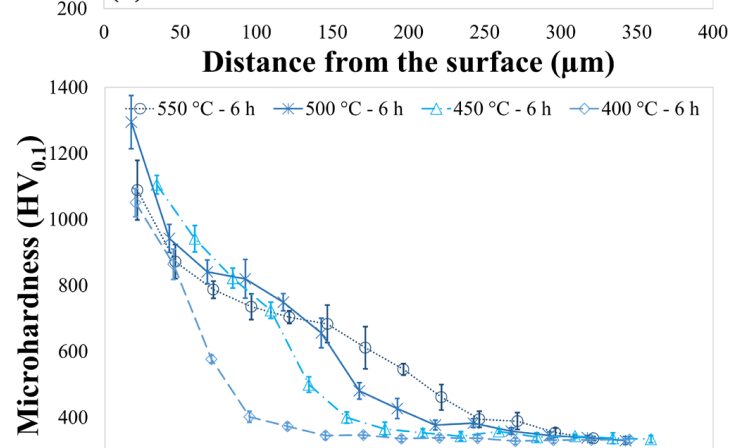

(b)
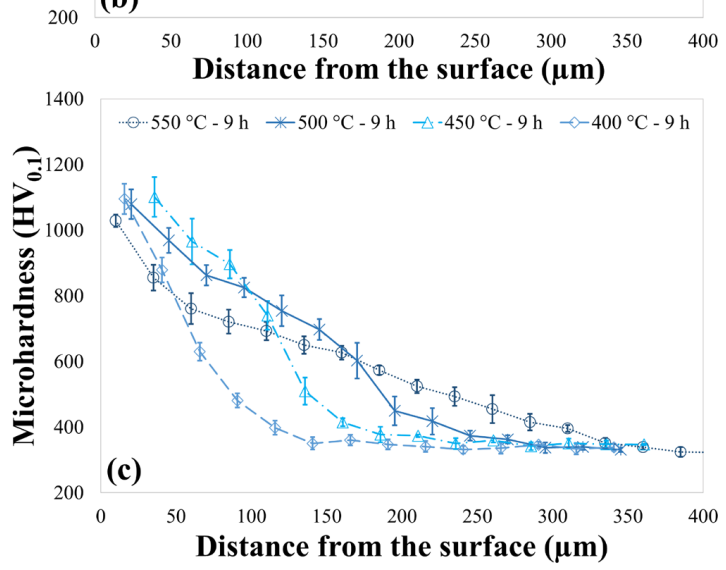

Figure 3. Microhardness profiles of plasma nitrided samples at 400 450, 500 and $550{ }^{\circ} \mathrm{C}$ for (a) $3 \mathrm{~h}$, (b) $6 \mathrm{~h}$ and (c) $9 \mathrm{~h}$.

\subsection{Reciprocating dry sliding wear tests}

In this work, the friction coefficients (COF) approach obtained on the wear tests will be carried out in two regions: at the beginning on the wear tests, Figure 6a-d, and at the time of microcracks formation or delamination of the surface layer, Figure 7a-d. The compound layer of the group of plasma nitrided samples at temperatures of 400,450 and $500{ }^{\circ} \mathrm{C}$ is similar (from point of view of the COF), with less roughness and more importantly the characteristics of the compound layer, as specifying the images shown in Figure $6 \mathrm{a}-\mathrm{d}$. For the group of plasma nitrided samples at $550{ }^{\circ} \mathrm{C}$, the $\mathrm{COF}$ is very low since the beginning of the tests, regardless of the treatment time. Regardless of the nitriding temperature, at the beginning of the reciprocal sliding wear test, the behavior of the nitrided samples in $9 \mathrm{~h}$ is similar at all temperatures. This is justified due to the fact that the hardness of the compound layer is similar among the group of plasma nitrided samples in $9 \mathrm{~h}$, Table 2 . Even with the 


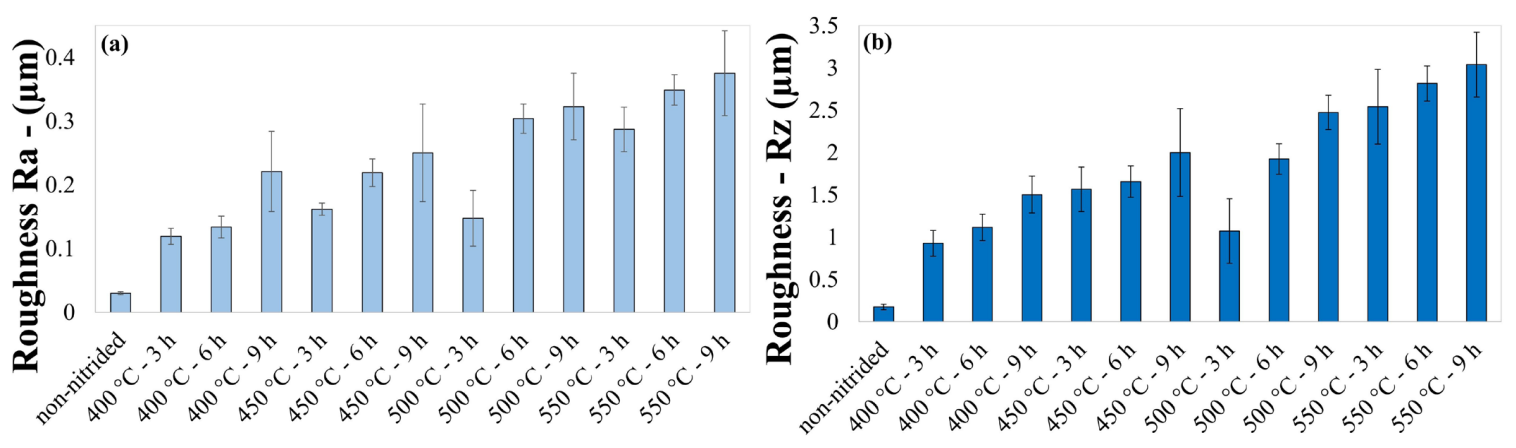

Figure 4. Roughness measurements before and after plasma nitriding at different temperatures and times: (a) $R_{a}$; (b) $R_{z}$.

(a)

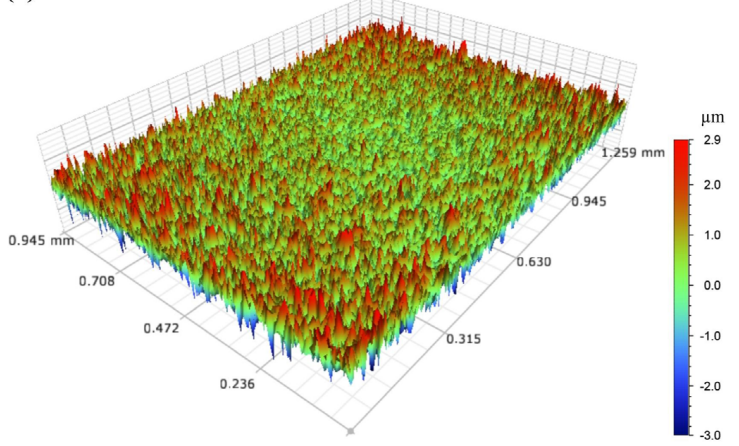

(b)

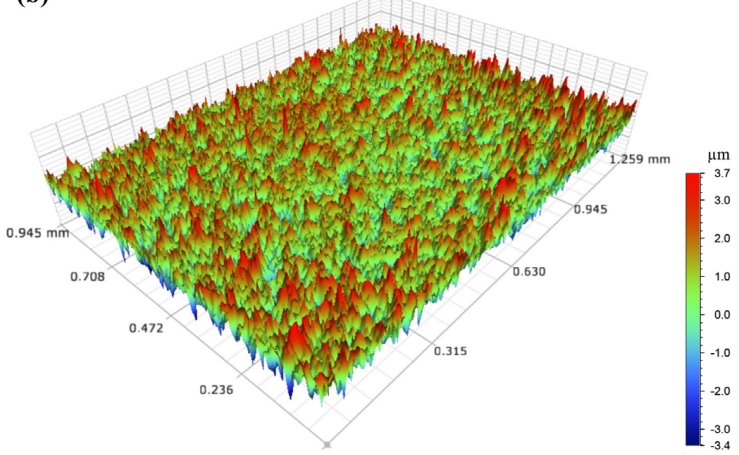

Figure 5. Surface representative images of plasma nitrided samples for $9 \mathrm{~h}$ at: (a) $400{ }^{\circ} \mathrm{C}$; (b) $500{ }^{\circ} \mathrm{C}$.
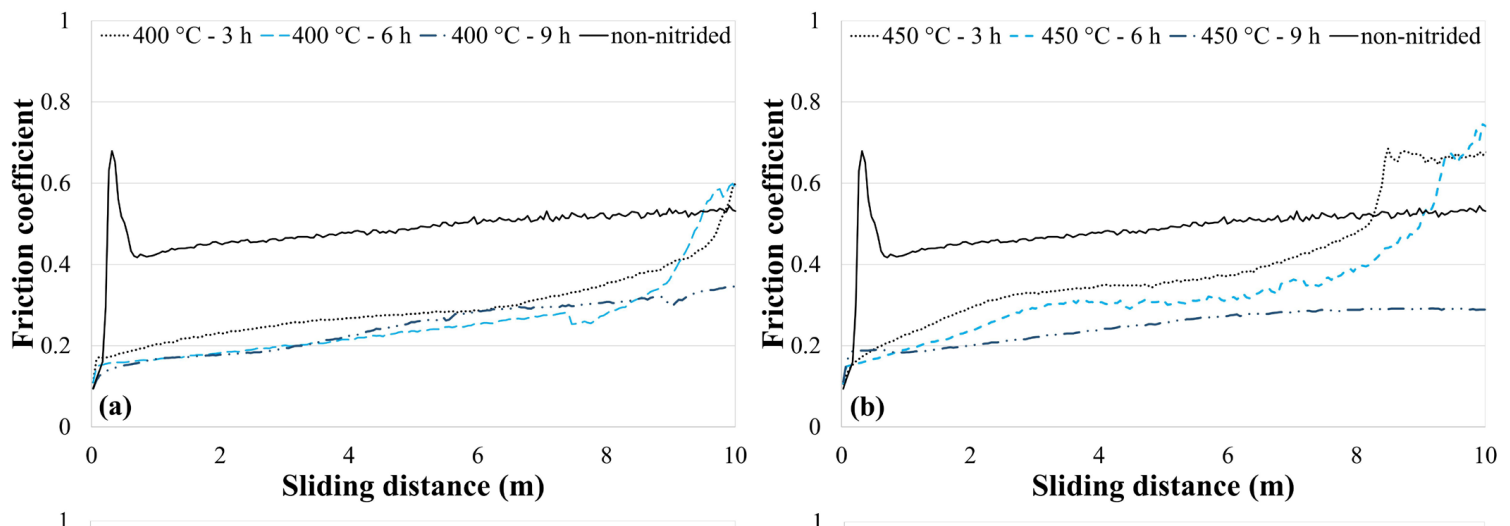

…...500 $50{ }^{\circ} \mathrm{C}-3 \mathrm{~h}--500{ }^{\circ} \mathrm{C}-6 \mathrm{~h}-.500{ }^{\circ} \mathrm{C}-9 \mathrm{~h}-$ non-nitrided

...... $5500^{\circ} \mathrm{C}-3 \mathrm{~h}--550{ }^{\circ} \mathrm{C}-6 \mathrm{~h}-.550^{\circ} \mathrm{C}-9 \mathrm{~h}$-non-nitrided
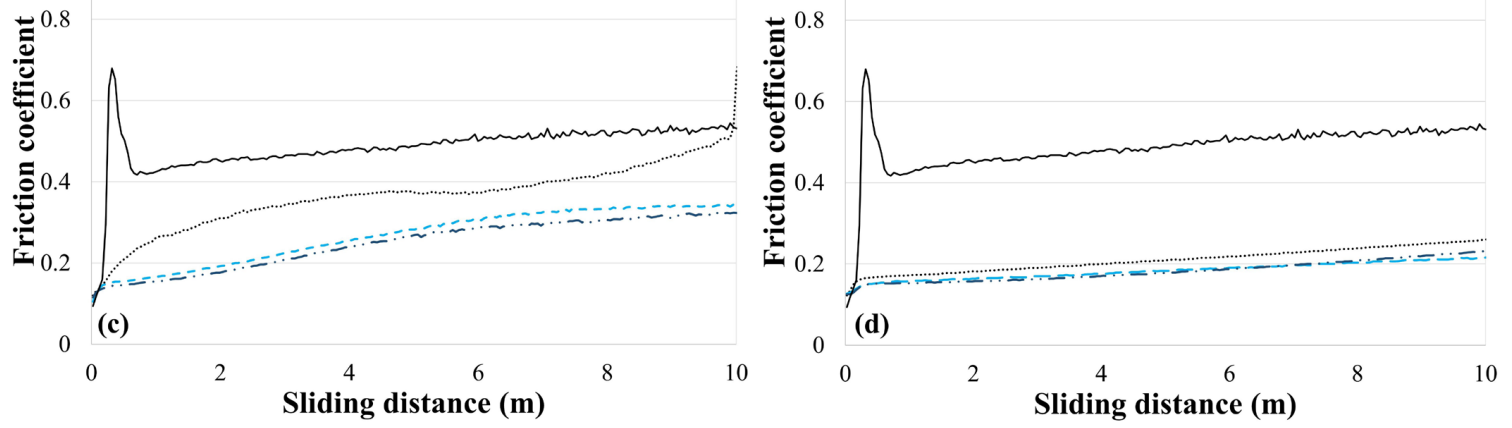

Figure 6. Friction coefficient obtained at the beginning on the reciprocating wear tests on non-nitrided samples and plasma nitrided samples for 3,6 and $9 \mathrm{~h}$ at (a) $400{ }^{\circ} \mathrm{C}$, (b) $450{ }^{\circ} \mathrm{C}$, (c) $500{ }^{\circ} \mathrm{C}$ and (d) $550{ }^{\circ} \mathrm{C}$. 


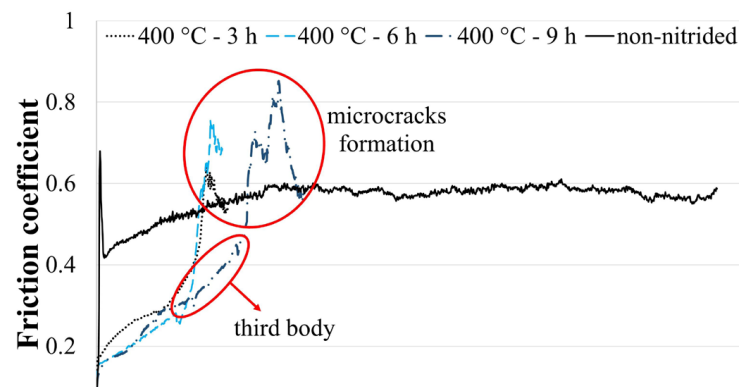

(a)

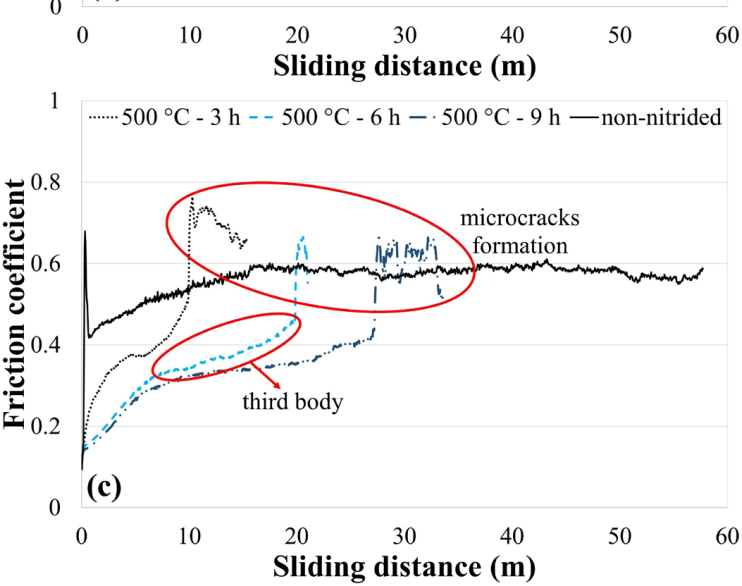

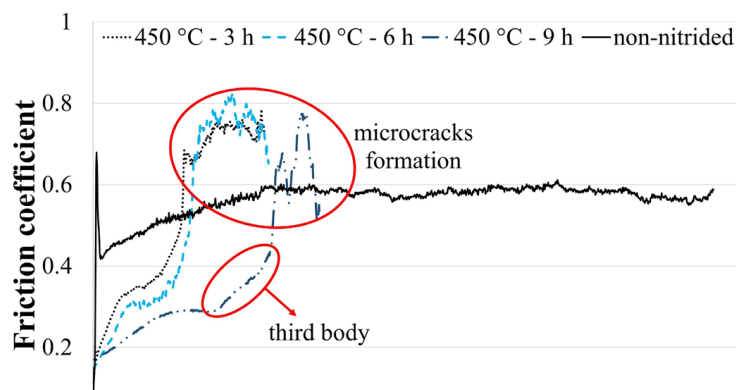

(b)

0

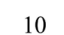

$20 \quad 30 \quad 40$

Sliding distance $(\mathrm{m})$
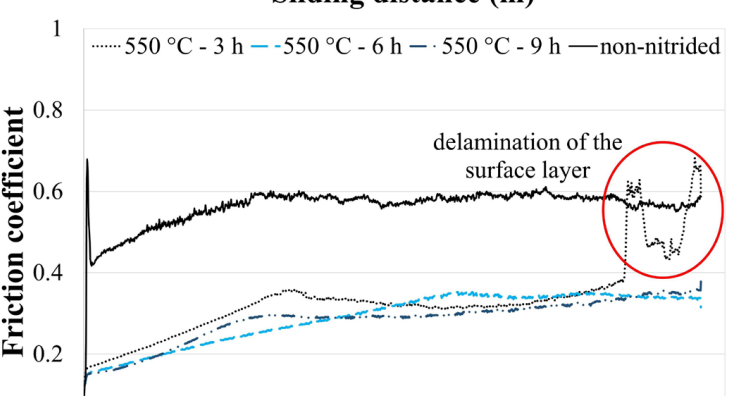

(d)

0

10

20

Sliding distance $(\mathbf{m})$

Figure 7. Friction coefficient obtained at the time of microcracks formation or delamination of the surface layer in reciprocating wear tests on non-nitrided samples and plasma nitrided samples for 3,6 and $9 \mathrm{~h}$ at (a) $400{ }^{\circ} \mathrm{C}$, (b) $450{ }^{\circ} \mathrm{C}$, (c) $500{ }^{\circ} \mathrm{C}$ and (d) $550{ }^{\circ} \mathrm{C}$.

Table 3. $\mathrm{P}_{\text {-value }}$ obtained through a two-way analysis of variance.

\begin{tabular}{lccc}
\hline \multicolumn{1}{c}{ Input Factor } & Case depth & Surface hardness & \multicolumn{2}{c}{ Sliding distance** } \\
\hline Temperature & $0.00^{*}$ & $0.00^{*}$ & $0.00^{*}$ \\
\hline Time & $0.00^{*}$ & 0.03 & 0.01 \\
\hline Temperature*Time & 0.68 & 0.01 & 0.16 \\
\hline
\end{tabular}

*The Minitab software package displays the $\mathrm{P}_{\text {-value }}=0$ when the results tend to zero. **Sliding distance at the time of microcracks formation or delamination of the surface layer.

roughness being lower in the non-nitrided samples and in the nitrided samples in $3 \mathrm{~h}$, the COF is higher, and this is related to an adhesion effect as being preponderant for this tribological system.

The average COF of the non-nitrided samples was $0.56 \pm 0.05$ (admitting that the steady-state occurs from $30 \mathrm{~m}$ ), Figure $7 \mathrm{a}-\mathrm{d}$. The non-nitrided samples stabilizes the friction values around $0.56 \pm 0.05$ in a test of up to $30 \mathrm{~m}$ of sliding distance, which did not occur for the plasma nitrided samples (with the exception from plasma nitrided samples at $550{ }^{\circ} \mathrm{C}$ for 6 and $9 \mathrm{~h}$ ). The results show that the nitriding treatments were responsible for the reduction of the COF, Figure 6a-d, this can be attributed to the increase in hardness (Table 2) and the contact area between ball and surface, which reflects in smaller deformations in contact surfaces and depends on elastic deformations. The lower $\mathrm{COF}$ at first occurs due to the ceramic characteristics of the compound layer ${ }^{40,41}$. The increase in COF, over time of wear is due to the presence of the third body of the ball and of the compound layer that was wearing out. As shown in Figure 7a-c, the sudden growth of COF is related to the wear of the surface layer that exposes the diffusion zone. When the diffusion zone is reached, the friction rises and may even reach or exceed the friction of the non-nitrided samples. Some local damage, results in the propagation of microcracks ${ }^{42,43}$ or delamination of the surface layer ${ }^{43}$.

Figure 8a shows a SEM image of the worn section of the ball tested at a load of $6 \mathrm{~N}$, and Figure 8b, c show an EDS analysis of the worn section of the ball. As shown in Figure 8a, b, the possibility of material detachment (in a region already weakened by microcracks) or delamination mechanism. Both mechanisms are characteristic of dry sliding wear tests.

The plasma nitrided samples at $550{ }^{\circ} \mathrm{C}$ for $3 \mathrm{~h}$ showed an abrupt increase in COF in approximately $53 \mathrm{~m}$ of sliding distance. As shown in Figure 9a, b and the profile of the track with pile-up, the high plastic deformation of the substrate contributed to delaminate the compound layer, exposing the diffusion zone, and raising the COF. Therefore, greater case depth (Table 2) tends to prevent the pile-up formation and prevent the sudden delamination of the surface layer. The plasma nitrided samples at $550^{\circ} \mathrm{C}$ for 6 and $9 \mathrm{~h}$ did not 

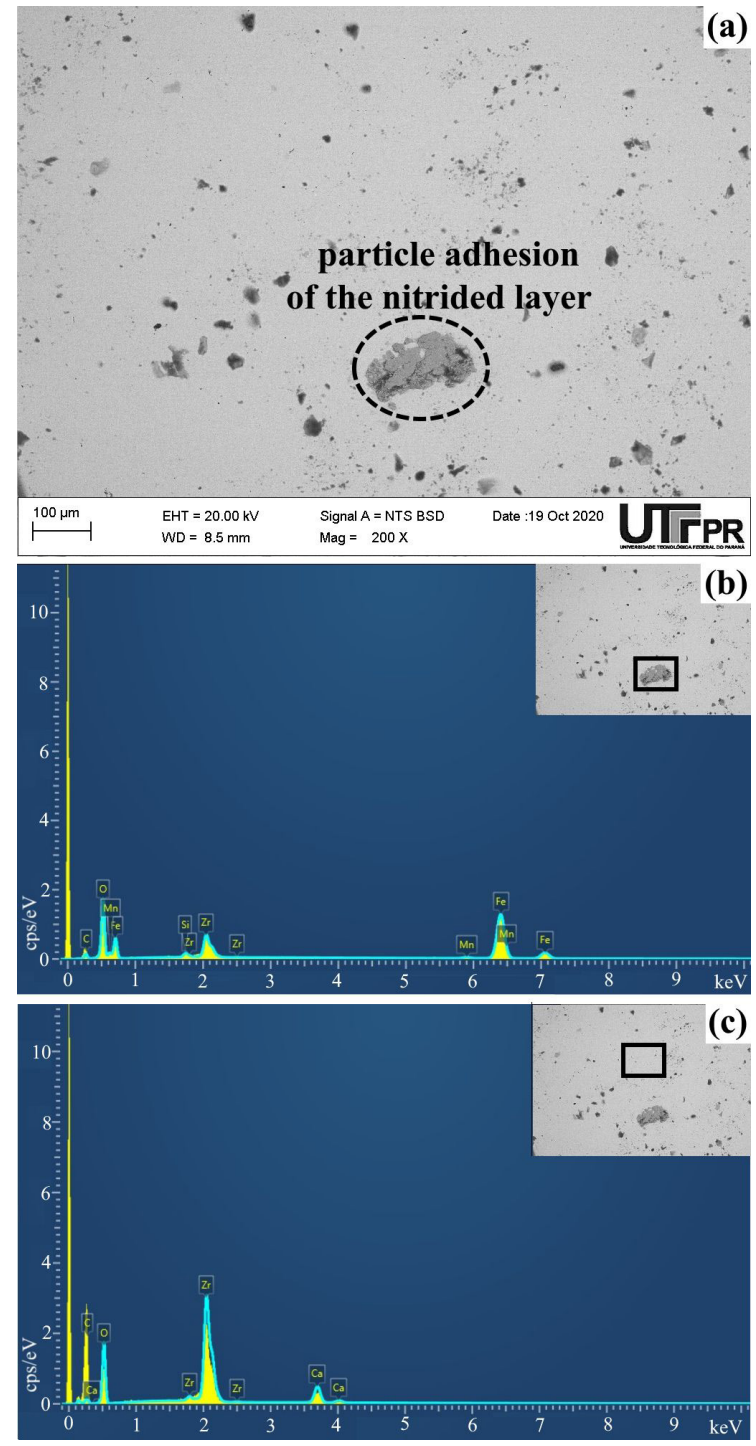

Figure 8. (a) SEM image and (b, c) EDS analysis of the ball after reciprocal sliding wear against on plasma nitrided samples at $500{ }^{\circ} \mathrm{C}$.

show an abrupt COF growth, Figure $7 d$, associated with the microcracks formation or delamination of the surface layer, confirmed by SEM/EDS, Figure 10a-d. However, the test was interrupted before the complete spalling of the plasma nitrided surfaces (Table 2). In general, the higher nitriding temperatures promoted an increase in the compound layer thickness ${ }^{44,45}$. This increase associated with the $\varepsilon-\mathrm{Fe}_{2-3}(\mathrm{C}) \mathrm{N}$ phase, which according to Doan et al. ${ }^{46}$ has a lower friction coefficient, Figure 2a-c, provided the bearing capacity of the compound layer, preventing the beginning formation of microcracks or delamination, as seen in Figure 11a, b. Another factor that must be acting strongly in this case is the softer hardness gradient between the surface and core of the plasma nitrided samples at $550{ }^{\circ} \mathrm{C}$, see Figure 3a-c.

Another fact observed, in EDS analyses by Figure 10c, d and cross-section profiles was the deposition of particles from the zirconia ball on the worn tracks of plasma nitrided samples at $550^{\circ} \mathrm{C}$ for 6 and $9 \mathrm{~h}$. In general, all plasma nitrided samples showed zirconia deposition on the worn tracks. As only slight wear occurred in the plasma nitrided samples at $550^{\circ} \mathrm{C}$ for 6 and $9 \mathrm{~h}$, the SEM/EDS analysis, Figure 10a-d detected only particles of third body generated by the wear of the zirconia ball.

Figure 9c, d, Figure 10c, $d$ and Figure 11c, $d$ also show the EDS analyses carried out on the worn tracks after reciprocal sliding wear to identify the chemical elements present in the surface of the plasma nitrided samples, in addition to the zirconia transferred from balls to the tracks. The peaks associated with the core steel lose intensity in samples with higher compound layer thickness, that is, in plasma nitrided samples at higher temperatures $\left(500\right.$ and $\left.550{ }^{\circ} \mathrm{C}\right)$.

Studies developed by Dutrey et al. ${ }^{47}$ show that the plasma nitriding with a nitrogen rich gas composition on a low-alloy steel (AISI 4140) formed intergranular fracture mode in the diffusion zone, related to nitride precipitation at grain boundaries. Despite the gas mixture of 76 vol. $\% \mathrm{~N}_{2}$ can be used to improve the surface properties of the DIN $18 \mathrm{MnCrSiMo6}-4$ steel, the nitrogen rich gas composition showed precipitation of nitrides, carbo-nitrides or carbides at grain boundaries for plasma nitriding of M2 high-speed steel ${ }^{44}$. It is known that grain boundary precipitation increases with time and temperature ${ }^{44,45}$. The presence of precipitation at grain boundaries results in brittleness of the diffusion $z^{2} e^{44,48}$, and this can lead to the delamination of the surface layer, Figure $9 \mathrm{a}, \mathrm{b}$ and Figure 11a, b, or even spalling.

The pile-up ${ }^{42}$ of tracks were analyzed from the crosssections, according to Figure 12. As inferred from the cross-section profiles illustration (Figure 12) and case depth (Table 2), tracks did not reach the substrate in the plasma nitrided surfaces. The friction and wear results can be associated to the operating wear mechanism found in the plasma nitrided samples. Observing a cross-section profile view of tracks revealed in the optical interferometry, one can note the absence of pile-up for the group of plasma nitrided samples at 550 and $500{ }^{\circ} \mathrm{C}$ for 6 and $9 \mathrm{~h}$ and $450{ }^{\circ} \mathrm{C}$ for $9 \mathrm{~h}$. For the group of plasma nitrided samples at 550 and $500^{\circ} \mathrm{C}$ for $3 \mathrm{~h}, 450^{\circ} \mathrm{C}$ for 3 and $6 \mathrm{~h}$ and $400^{\circ} \mathrm{C}$ for 3,6 and $9 \mathrm{~h}$, it was verified of pile-up, resulting in the predominance of plastic deformation. As mentioned before, samples presenting higher case depths, exhibited lower plastic deformation, since the diffusion zone provided the bearing capacity of the compound layer.

In order to evaluate the statistical significance of treatment temperature and time on the case depth, surface hardness and sliding distance on the time for microcracks formation or delamination of the surface layer, the collected data results were analyzed using the Minitab 16 software. The results of the interaction plot by analysis of variance are shown in Figure 13a-c. The interaction plot demonstrates how the relationship between a categorical factor and a continuous response depends on the value of the second categorical factor. The interaction strength is greater when the lines in the graphs are non-parallel ${ }^{49}$.

From a statistical point of view (Table 3), it is noticed that the case depth was influenced by the temperature $\left(\mathrm{P}_{\text {-value }}=0.00<\alpha=0.05\right)$ and time $\left(\mathrm{P}_{\text {-Value }}=0.00<\alpha=0.05\right)$ parameters, but there was no synergistic effect between temperature and treatment time $\left(\mathrm{P}_{\text {-value }}=0.68>\alpha=0.05\right)$, 


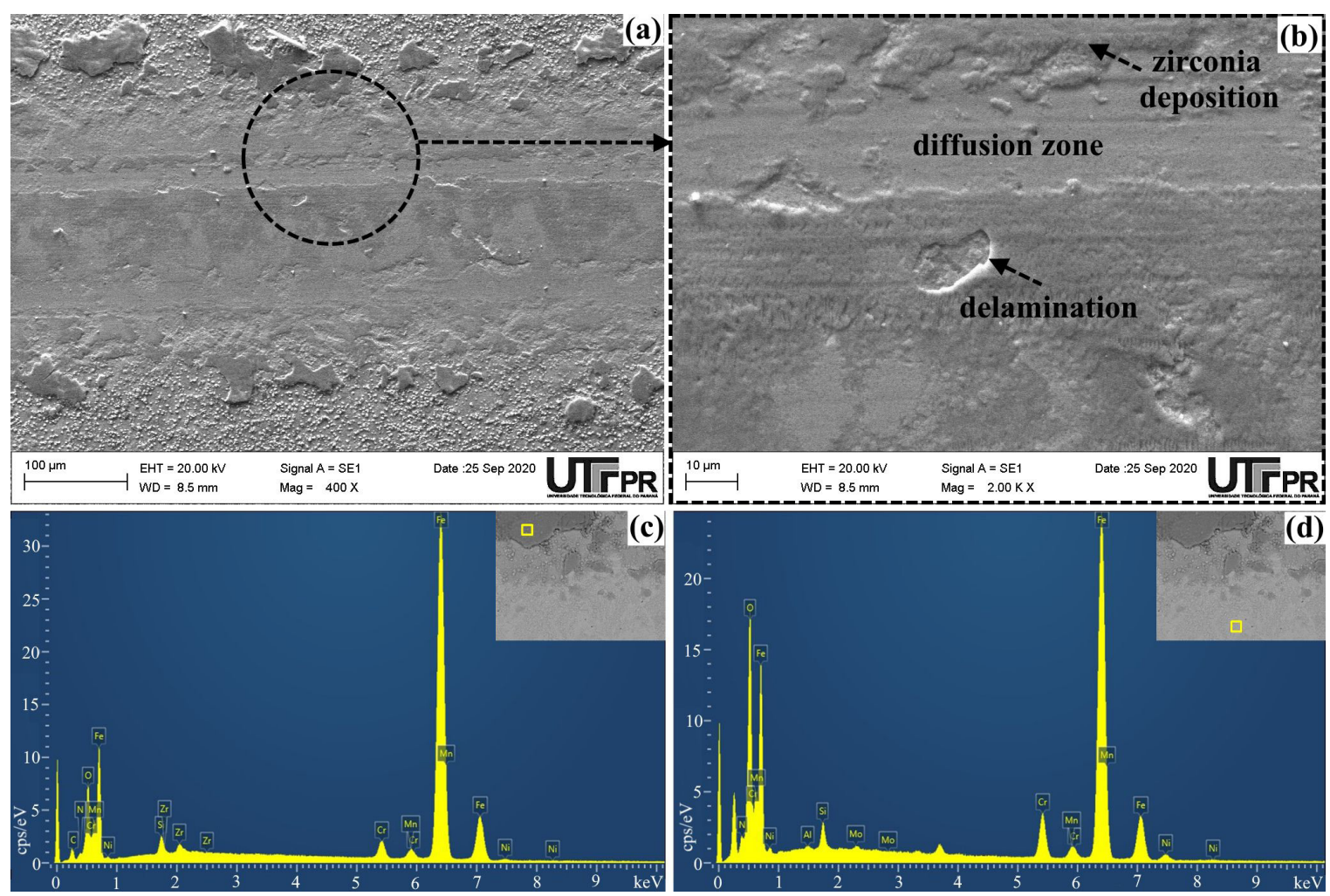

Figure 9. (a, b) SEM images and (c, d) EDS analysis of the wear tracks after reciprocal sliding wear of plasma nitrided samples at $550{ }^{\circ} \mathrm{C}$ for $3 \mathrm{~h}$.

Figure 13a, because there is a competition between sputter yield and nitrogen uptake. Tukey's-b post hoc test shows that the case depth has a significant difference between the times of 3 and $6 \mathrm{~h}$, with a technical tie between 6 and $9 \mathrm{~h}$. As for the case depth, the temperature that showed the best response was the nitriding performed at $550{ }^{\circ} \mathrm{C}$, confirmed by the Tukey's-b post hoc test.

As can be seen in Figure 13b, the surface hardness behavior of the samples remained relatively close. Both factors studied temperature and time showing statistical relevance $\left(\mathrm{P}_{\text {-value }}=0.01<\alpha=0.05\right)$ and were presented in Table 3. Tukey's-b post hoc test showed that although the temperature is significant in increasing the surface hardness, the difference between the results obtained in the time variation was not greater than three times the standard deviation. Tukey's-b post hoc test between the different temperatures showed that there was a significant increase between 400 and $500{ }^{\circ} \mathrm{C}$. Regarding the hardness profile, the plasma nitrided samples at $550{ }^{\circ} \mathrm{C}$ did not show any significant difference with nitriding performed at $500{ }^{\circ} \mathrm{C}$, but in terms of surface hardness, the best temperature was $500{ }^{\circ} \mathrm{C}$. The time should be determined according to the need for the case depth. However, as previously discussed, Figure 13a, low case depths (compound layer + diffusion layer) provided the pile-up formation. Therefore, as there was a statistical tie on the wear of the plasma nitrided samples at 6 and $9 \mathrm{~h}$ at $550^{\circ} \mathrm{C}$, Figure $13 \mathrm{c}$, the use of $6 \mathrm{~h}$ is recommended, due to the process cost.
Figure $13 \mathrm{c}$ shows that the sliding distance at the time of microcracks or delamination of the surface layer had no synergistic effect $\left(\mathrm{P}_{\text {-Value }}=0.16>\alpha=0.05\right)$, and that the main effects were more important (Table 3 ). However, the input parameters: temperature $\left(\mathrm{P}_{\text {-Value }}=0.00<\alpha=0.05\right)$ and time $\left(\mathrm{P}_{\text {-Value }}=0.01<\alpha=0.05\right)$ had significant effects on the sliding distance until the abrupt increase in COF, Figure 7a-d. By Tukey's-b post hoc test analysis the nitriding time did not show differences greater than three times the standard deviation in the sliding distance. However, low nitriding times generated smaller case depth and favored the pile-up formation which, in some cases, contributed to delamination of the surface layer. The temperature variation analysis showed that the ideal temperature for increasing the sliding distance before the abrupt increase in $\mathrm{COF}$ and the consequent increase in wear resistance occur at $550{ }^{\circ} \mathrm{C}$. The best performance for reciprocating dry sliding wear tests was found in plasma nitrided samples at $550^{\circ} \mathrm{C}$ with nitriding time of $6 \mathrm{~h}$.

\subsection{Final discussion}

The compilation of case depth, surface hardness and sliding distance at the time of microcracks formation or delamination of the surface layer of plasma nitrided samples are given in Table 2. Time and temperature can influence not only the compound layer thickness, but also its composition. The X-ray analysis, Figure 2a-c, showed the formation of biphasic compound layer, $\varepsilon-\mathrm{Fe}_{2-3}(\mathrm{C}) \mathrm{N}$ and $\gamma^{\prime}-\mathrm{Fe}_{4} \mathrm{~N}$, for in all treatment conditions. It might normally be expected that 


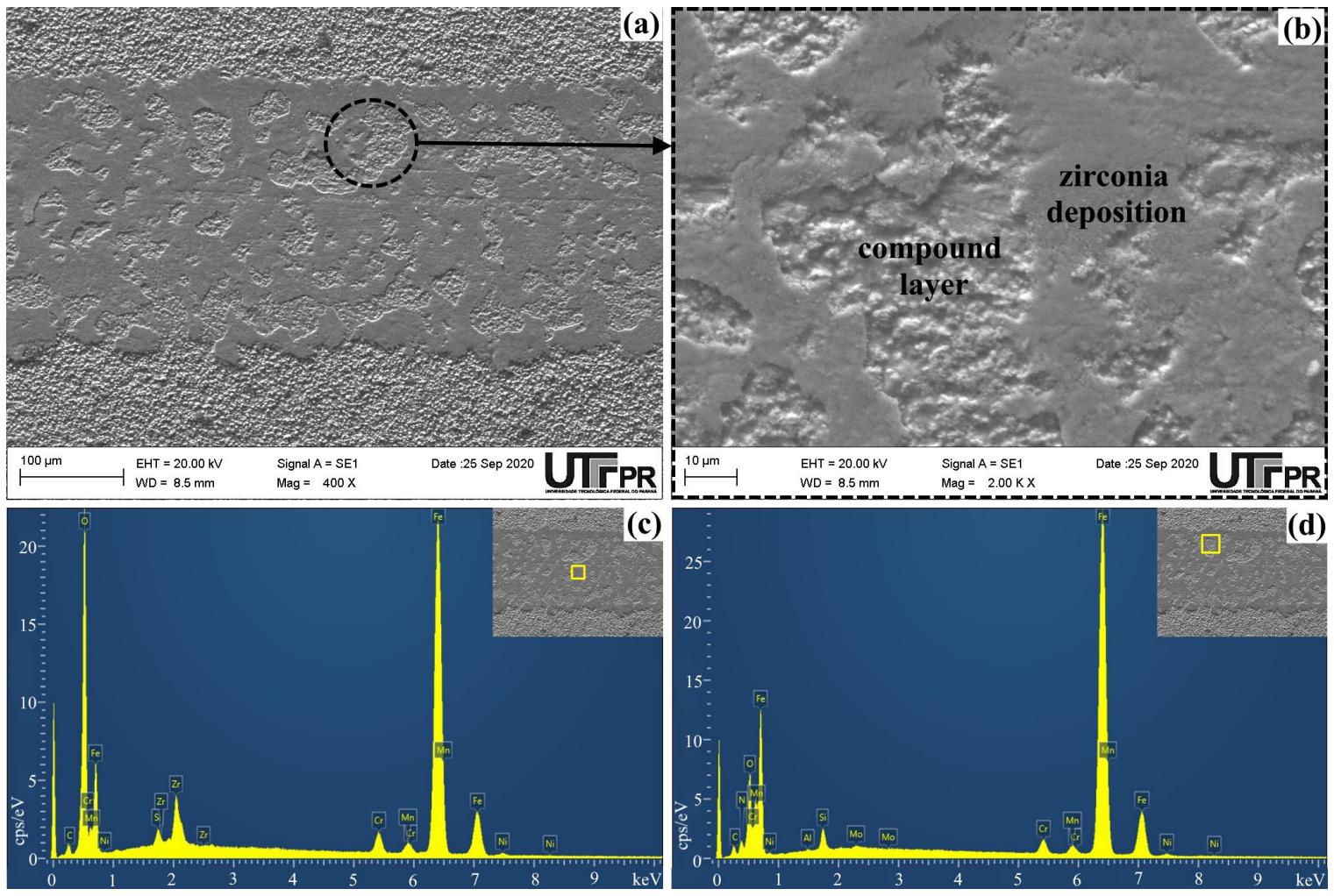

Figure 10. (a, b) SEM images and (c, d) EDS analysis of the wear tracks after reciprocal sliding wear of plasma nitrided samples at $550{ }^{\circ} \mathrm{C}$ for $9 \mathrm{~h}$ (as a representative result of plasma nitrided samples at $550{ }^{\circ} \mathrm{C}$ for 6 and $9 \mathrm{~h}$ ).

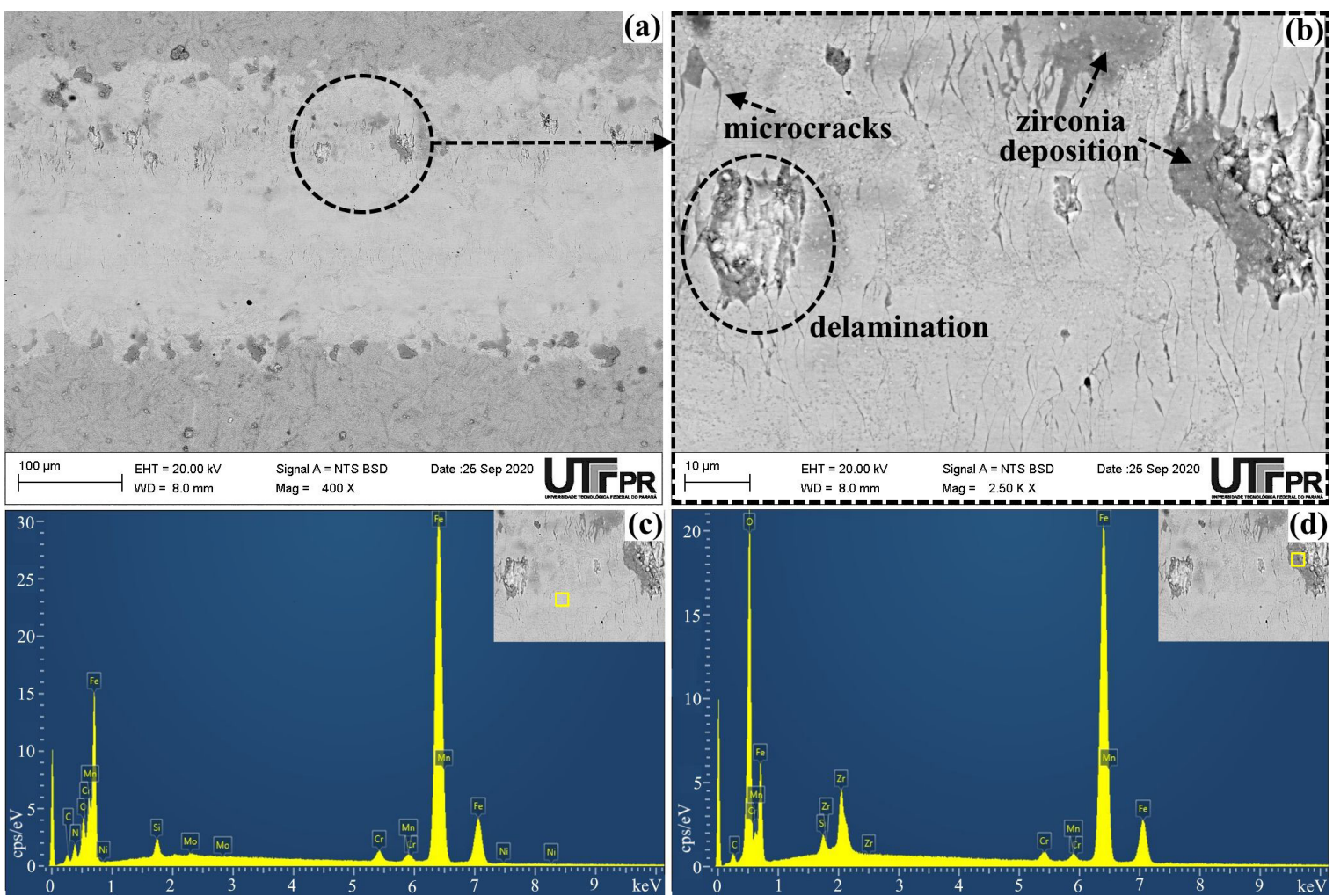

Figure 11. (a, b) SEM images and (c, d) EDS analysis of the wear tracks after reciprocal sliding wear of plasma nitrided samples at $450{ }^{\circ} \mathrm{C}$ for $9 \mathrm{~h}$ (as a representative result of plasma nitrided samples at 400,450 and $500{ }^{\circ} \mathrm{C}$ for 3,6 and $9 \mathrm{~h}$ ). 


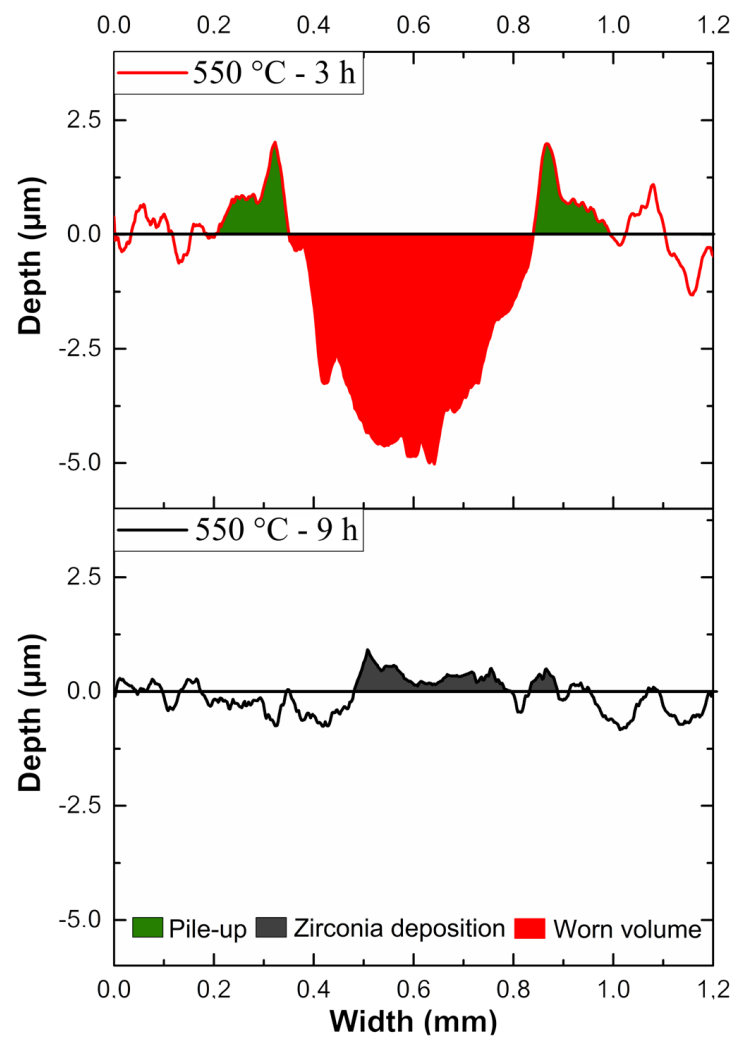

Figure 12. Cross-section profiles illustration of tracks produced in reciprocating wear tests on the plasma nitrided surfaces.

the compound layer containing predominant $\varepsilon-\mathrm{Fe}_{2-3}(\mathrm{C}) \mathrm{N}$ has higher hardness than the compound layer monophasic containing $\gamma^{\prime}-\mathrm{Fe}_{4} \mathrm{~N}$. For nitriding temperatures up to $500^{\circ} \mathrm{C}$, hardness increases with treatment temperature and time. The observed behaviour seems to be governed, by the increase of the compound layer thickness. For $550{ }^{\circ} \mathrm{C}$ on the other hand, the surface hardness is lower than for $500{ }^{\circ} \mathrm{C}$, which happened due to the overheating of the substrate, as core hardness decreased for this temperature ${ }^{15,17}$. Concerning the sliding distance at the time of microcracks formation or delamination of the surface layer, as nitriding temperature and time increased to $500{ }^{\circ} \mathrm{C}$, the compound layer also increased. The same happened to the sliding distance and the worn volume, as expected. For the group of plasma nitrided samples at $550{ }^{\circ} \mathrm{C}$ for 6 and $9 \mathrm{~h}$ did, no delamination of the surface layer (even at a sliding distance of $58 \mathrm{~m}$ ), was observed. Actually, a marked wear of the zirconia balls took place for these testing conditions. The plasma nitrided surfaces presented a lower COF again zirconia ball than nonnitrided steel. When the surface layer starts to delaminate, the friction coefficient quickly exceeds the substrate values.

The statistical analysis showed, with $95 \%$ of statistical confidence, that the best setup to resist dry sliding reciprocal wear on the tested configuration was plasma nitriding at $550{ }^{\circ} \mathrm{C}$ for $6 \mathrm{~h}$. However, Dalcin et al. ${ }^{15}$ showed that the core hardness of samples nitrided at $550{ }^{\circ} \mathrm{C}$ was impaired. Therefore, for practical applications in components such as gears, the use at $500^{\circ} \mathrm{C}$ is recommended, due to temperatures

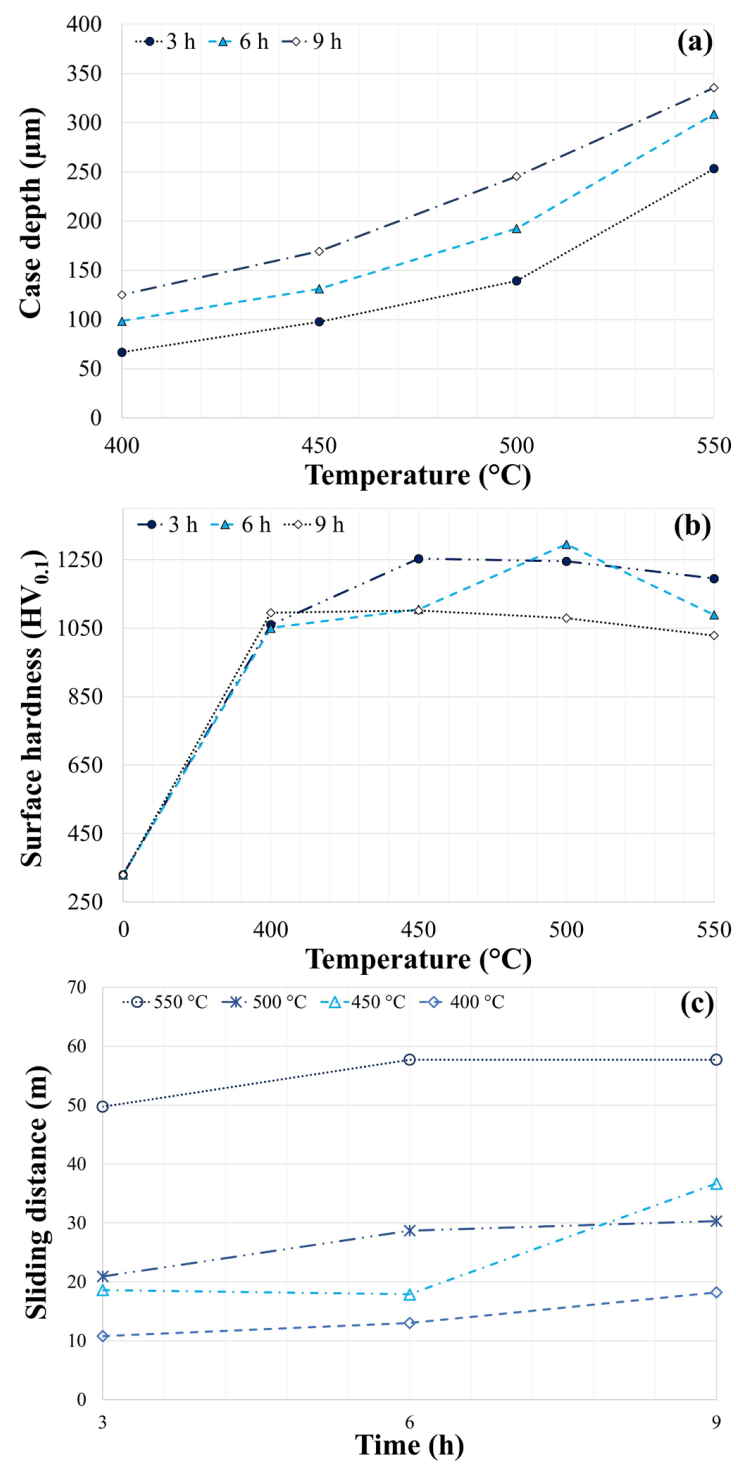

Figure 13. Analysis of variance. Interaction plot of temperature and nitriding time with: (a) Case depth; (b) Surface hardness; (c) Sliding distance at the time of microcracks formation or delamination of the surface layer.

at 400 and $450{ }^{\circ} \mathrm{C}$ would require too long treatment times to produce the appropriate case depth.

In this work, it was found that the gas mixture of $76 \mathrm{vol} . \%$ $\mathrm{N}_{2}$ can be used to improve the surface properties of the DIN 18MnCrSiMo6-4 steel, but this nitrogen rich gas composition can cause embrittlement of the diffusion zone, mainly in high carbon steels ${ }^{44,45}$. The embrittlement is associated with the formation of precipitates in the grain boundary ${ }^{44,48}$, but for steels with a low carbon, the embrittlement does not seem to be as intense. In order to avoid the embrittlement of the diffusion zone, a new study using a gas mixture with a lower nitrogen composition would be indicated. This issue will be addressed in future work.

\section{Conclusions}


- $\quad$ Plasma nitriding of DIN 18MnCrSiMo6-4 continuous cooling bainitic steel is viable, since it demonstrated good response to the process with excellent results regarding layer depth and surface hardness. All plasma nitriding treatments were able to form a compound layer and generate a significant increase in surface hardness, raising it from $329.8 \mathrm{HV}_{0.1}$ in the material core to values above $1000 \mathrm{HV}_{0.1}$;

- Plasma nitriding treatments were responsible for the reduction of the friction coefficient. The lower friction at first occurs due to the ceramic characteristics of the compound layer. The increase in COF, over time of wear is due to the presence of the third body of the ball and of the compound layer that was wearing out. The sudden growth of $\mathrm{COF}$ is related to the wear of the surface layer that exposes the diffusion zone. When the diffusion zone is reached, the friction rises and may even reach or exceed the friction of the non-nitrided samples;

- If assessing the wear mechanisms, only the samples that have greater case depth (compound layer + diffusion zone), the diffusion zone supports the compound layer. This causes the wear to be slower, precisely because the beginning wear is in the hardest region of the compound layer until it reaches less hard regions. For this reason, this transition is smoother and takes longer before microcracks or delamination appears. In the case of plasma nitrided samples at $550{ }^{\circ} \mathrm{C}$ for 6 and $9 \mathrm{~h}$, the wear test would have to be extended for a longer time until the damage mentioned above appears;

- $\quad$ Since that the plasma nitrided samples at $550^{\circ} \mathrm{C}$ have a thicker compound layer and diffusion zone higher than the other conditions investigated, these samples showed better wear performances in the ball-on-flat reciprocal dry sliding than the other groups investigated. The nitrided layer formed in the treatment at $550{ }^{\circ} \mathrm{C}$ for $6 \mathrm{~h}$ present the best performance for the tested conditions, with $95 \%$ of statistical confidence.

\section{Acknowledgments}

This work was carried out with the support of CAPES, a Brazilian government entity focused on human resources training, with the support of CAPES BRAGECRIM PROGRAM (Process no. 88881.142485/2017-01 - aid number 1844/2017) and CAPES - PROEX (Process 23038.000341/2019-71). R. L. Dalcin acknowledges CAPES (Grant 88882.345854/2019-01), V. V. de Castro acknowledges CNPq (Grant 166262/2018-8), L. F. Oliveira acknowledges CAPES (Grant 88882.345860/2019-01), C. F. Malfatti acknowledges CNPq (Grant 307723/2018-6) and A. S. Rocha acknowledges CNPq (Grant 308773/2018-7). The authors acknowledge the Laboratório de Superfícies e Contato (LASC) and Centro Multiusuário de Caracterização de Materiais (CMCM) of Universidade Tecnológica Federal do Paraná (UTFPR).

\section{References}

1. Luo Y, Peng J, Wang H, Wu X. Effect of tempering on microstructure and mechanical properties of a non-quenched bainitic steel. Mater Sci Eng A. 2010;527:3433-7. http://dx.doi. org/10.1016/j.msea.2010.02.010.

2. Lembke MI, Olschewski G, Roelofs H, Klümper-Westkamp H. Nitrieren von hochfesten, bainitischen Langprodukten*. HTM. 2014;69:195-200. http://dx.doi.org/10.3139/105.110226.

3. Buchmayr B. Critical Assessment 22: bainitic forging steels. Mater Sci Technol. 2016;32:517-22. http://dx.doi.org/10.108 0/02670836.2015.1114272.

4. Silveira ACF, Bevilaqua WL, Dias VW, Castro PJ, Epp J, Rocha AS. Influence of hot forging parameters on a low carbon continuous cooling bainitic steel microstructure. Metals (Basel). 2020;601:11. http://dx.doi.org/10.3390/met10050601.

5. Lemos Bevilaqua W, Epp J, Meyer H, Da Silva Rocha A, Roelofs H. In situ investigation of the bainitic transformation from deformed austenite during continuous cooling in a low carbon Mn-Si-Cr-Mo steel. Metall Mater Trans, A Phys Metall Mater Sci. 2020;51:3627-37. http://dx.doi.org/10.1007/s11661020-05800-6.

6. Dong J, Skalecki MG, Hatwig RA, Bevilaqua WL, Stark A, Epp J, et al. Study of microstructural development of bainitic steel using eddy current and synchrotron XRD in-situ measurement techniques during thermomechanical treatment. HTM. 2020;75:3-22. http://dx.doi.org/10.3139/105.110402.

7. Hatwig RA, Dong J, Epp J, Rocha AS. Effect of compressive deformations on the final microstructure of a low carbon high silicon bainitic steel thermomechanically processed. Mater Res. 2021;24:e20200346. http://dx.doi.org/10.1590/1980-5373$\mathrm{mr}-2020-0346$.

8. Caballero FG, Bhadeshia HKDH, Mawella KJA, Jones DG, Brown P. Design of novel high strength bainitic steels: Part 2. Mater Sci Technol. 2001;17:517-22. http://dx.doi. org/10.1179/026708301101510357.

9. Caballero FG, Santofimia MJ, García-Mateo C, Chao J, de Andrés CG. Theoretical design and advanced microstructure in super high strength steels. Mater Des. 2009;30:2077-83. http://dx.doi.org/10.1016/j.matdes.2008.08.042.

10. Caballero FG, Roelofs H, Hasler S, Capdevila C, Chao J, Cornide $\mathrm{J}$, et al. Influence of bainite morphology on impact toughness of continuously cooled cementite free bainitic steels. Mater Sci Technol. 2012;28:95-102. http://dx.doi.org/10.1179 /1743284710Y.0000000047.

11. Caballero FG, Santofimia MJ, Capdevila C, García-Mateo C, Andrés CGD. Design of Advanced Bainitic Steels by Optimisation of TTT Diagrams and T0 Curves. ISIJ Int. 2006;46:1479-88. http://dx.doi.org/10.2355/isijinternational.46.1479.

12. Matlock DK, Alogab KA, Richards MD, Speer JG. Surface processing to improve the fatigue resistance of advanced bar steels for automotive applications. Mater Res. 2005;8:453-9. http://dx.doi.org/10.1590/S1516-14392005000400017.

13. Dong J, Epp J, Rocha AS, Nunes RM, Zoch H-W. Investigation of the influence factors on distortion in induction-hardened steel shafts manufactured from cold-drawn rod. Metall Mater Trans, A Phys Metall Mater Sci. 2016;47:877-88. http://dx.doi. org/10.1007/s11661-015-3250-4.

14. Abdalla AJ, Santos D, Vasconcelos G, Baggio-Scheid VH, Silva DF. Changing in fatigue life of $300 \mathrm{M}$ bainitic steel after laser carburizing and plasma nitriding. MATEC Web Conf. 2018;165:21002. https://doi.org/10.1051/matecconf/201816521002.

15. Dalcin RL, Oliveira LF, Diehl IL, Dias VW, Rocha AS. Response of a DIN 18MnCrSiMo6-4 continuous cooling bainitic steel to plasma nitriding with a nitrogen rich gas composition. Mater Res. 2020;23:e20200036. http://dx.doi.org/10.1590/1980-5373mr-2020-0036. 
16. Dalcin RL, Oliveira LF, Diehl CATS, da Silva Rocha A. Response of a DIN 18MnCrSiMo6-4 continuous cooling bainitic steel to different plasma nitriding gas mixtures. Mater Res. 2020;23:e20200269. http://dx.doi.org/10.1590/1980-5373mr-2020-0269.

17. Ashrafizadeh F. Influence of plasma and gas nitriding on fatigue resistance of plain carbon (Ck45) steel. Surf Coat Tech. 2003;174-175:1196-200. http://dx.doi.org/10.1016/S02578972(03)00460-2.

18. Podgornik B, Vižintin J, Leskovšek V. Tribological properties of plasma and pulse plasma nitrided AISI 4140 steel. Surf Coat Tech. 1998;108-109:454-60. http://dx.doi.org/10.1016/ S0257-8972(98)00571-4.

19. Paschke H, Weber M, Kaestner P, Braeuer G. Influence of different plasma nitriding treatments on the wear and crack behavior of forging tools evaluated by Rockwell indentation and scratch tests. Surf Coat Tech. 2010;205:1465-9. http:// dx.doi.org/10.1016/j.surfcoat.2010.07.053.

20. Schibicheski Kurelo BCE, de Oliveira WR, Serbena FC, de Souza GB. Surface mechanics and wear resistance of supermartensitic stainless steel nitrided by plasma immersion ion implantation. Surf Coat Tech. 2018;353:199-209. http://dx.doi.org/10.1016/j. surfcoat.2018.08.079.

21. Zhao G-H, Aune RE, Espallargas N. Tribocorrosion studies of metallic biomaterials: the effect of plasma nitriding and DLC surface modifications. J Mech Behav Biomed Mater. 2016;63:100-14. http://dx.doi.org/10.1016/j.jmbbm.2016.06.014.

22. Luo Q, Oluwafemi O, Kitchen M, Yang S. Tribological properties and wear mechanisms of DC pulse plasma nitrided austenitic stainless steel in dry reciprocating sliding tests. Wear. 2017;376-377:1640-51. http://dx.doi.org/10.1016/j. wear.2016.12.022.

23. Pavlik A, Marcos G, Coulibaly M, Vincent J, Czerwiec T, Philippon S. Improving the surface durability of patterned AISI 316LM steels by nitriding treatment for dry friction sliding. Tribol Int. 2020;146:106232. http://dx.doi.org/10.1016/j. triboint.2020.106232.

24. Gražulis S, Daškevič A, Merkys A, Chateigner D, Lutterotti L, Quirós M, et al. Crystallography Open Database (COD): an open-access collection of crystal structures and platform for world-wide collaboration. Nucleic Acids Res. 2012;40:D420-7. http://dx.doi.org/10.1093/nar/gkr900.

25. ICSD. Karlsruhe, ICSD - Basic Search \& Retrieve [Internet]. 2020 [cited 2020 Dec 26]. Available from: https://icsd.fiz-karlsruhe.de/ index.xhtml; jsessionid=19DB93C9947356A41CB36145B5302A0C

26. Doebelin N, Kleeberg R. Profex: a graphical user interface for the Rietveld refinement program $B G M N$. J Appl Cryst. 2015;48:1573-80. http://dx.doi.org/10.1107/S1600576715014685.

27. ASTM International. ASTM E92: Test Methods for Vickers Hardness and Knoop Hardness of Metallic Materials. West Conshohocken: ASTM International; 2017.

28. DIN Deutsches Institut für Normung. DIN 50 190: Härtetiefe wärmebehandelter Tiele: Ermittlung der Nitrierhärtetiefe. Teil 3. Berlin: DIN Deutsches Institut für Normung; 1979.

29. International Organization for Standardization. ISO 4287: Geometrical product specifications (GPS) - surface texture: profile method - terms, definitions and surface texture parameters. Genebra: ISO; 2002.

30. International Organization for Standardization. ISO 4288: Geometrical product specifications (GPS) - surface texture: profile method - rules and procedures for the assessment of surface texture. Genebra: ISO; 2008.

31. ASTM International. ASTM G133: Test Method for Linearly Reciprocating Ball-on-Flat Sliding Wear. West Conshohocken: ASTM International; 2005. https://doi.org/10.1520/G013305R16.

32. Johnson KL. Contact mechanics. Cambridge: Cambridge University Press; 1985.
33. Ilhan-Sungur E, Çotuk A. Microbial corrosion of galvanized steel in a simulated recirculating cooling tower system. Corros Sci. 2010;52:161-71. http://dx.doi.org/10.1016/j.corsci.2009.08.049.

34. Kovács D, Quintana I, Dobránszky J. Effects of different variants of plasma nitriding on the properties of the nitrided layer. J Mater Eng Perform. 2019;28:5485-93. http://dx.doi. org/10.1007/s11665-019-04292-9.

35. Castro G, Fernández-Vicente A, Cid J. Influence of the nitriding time in the wear behaviour of an AISI H13 steel during a crankshaft forging process. Wear. 2007;263:1375-85. http:// dx.doi.org/10.1016/j.wear.2007.02.007.

36. Nolan D, Leskovsek V, Jenko M. Estimation of fracture toughness of nitride compound layers on tool steel by application of the Vickers indentation method. Surf Coat Tech. 2006;201:182-8. http://dx.doi.org/10.1016/j.surfcoat.2005.11.077.

37. Sun Y, Luo N, Bell T. Three-dimensional characterisation of plasma nitrided surface topography. Surf Eng. 1994;10:279-86. http://dx.doi.org/10.1179/sur.1994.10.4.279.

38. Lampe T, Eisenberg S, Laudien G. Compound layer formation during plasma nitriding and plasma nitrocarburising. Surf Eng. 1993;9:69-76. http://dx.doi.org/10.1179/sur.1993.9.1.69.

39. Giacomelli RO, Salvaro DB, Bendo T, Binder C, Klein AN, de Mello JDB. Topography evolution and friction coefficient of gray and nodular cast irons with duplex plasma nitrided + DLC coating. Surf Coat Tech. 2017;314:18-27. http://dx.doi. org/10.1016/j.surfcoat.2016.09.035.

40. Çomaklı O, Yetim AF, Karaca B, Çelik A. Effect of gas mixture on tribological performance of plasma nitrided grey cast iron under dry and lubricated conditions. Mater Res Express. 2019;6:056513. http://dx.doi.org/10.1088/2053-1591/ab012b.

41. Díaz-Guillén JC, Naeem M, Hdz-García HM, Acevedo-Davila JL, Díaz-Guillén MR, Khan MA, et al. Duplex plasma treatment of AISI D2 tool steel by combining plasma nitriding (with and without white layer) and post-oxidation. Surf Coat Tech. 2020;385:125420. http://dx.doi.org/10.1016/j.surfcoat.2020.125420.

42. Rovani AC, Breganon R, Souza GS, Brunatto SF, Pintaúde G. Scratch resistance of low-temperature plasma nitrided and carburized martensitic stainless steel. Wear. 2017;376-377:70-6. http://dx.doi.org/10.1016/j.wear.2017.01.112.

43. Lorenzo-Martin C, Ajayi O, Erdemir A, Fenske GR, Wei R. Effect of microstructure and thickness on the friction and wear behavior of CrN coatings. Wear. 2013;302(1-2):963-71. http:// dx.doi.org/10.1016/j.wear.2013.02.005.

44. Rocha AS, Strohaecker T, Hirsch T. Effect of different surface states before plasma nitriding on properties and machining behavior of M2 high-speed steel. Surf Coat Tech. 2003;165:17685. http://dx.doi.org/10.1016/S0257-8972(02)00768-5.

45. Silva Rocha A, Strohaecker T, Tomala V, Hirsch T. Microstructure and residual stresses of a plasma-nitrided M2 tool steel. Surf Coat Tech. 1999;115:24-31. http://dx.doi.org/10.1016/S02578972(99)00063-8.

46. Doan TV, Dobrocky D, Pokorny Z, Kusmic D, Nguyen VT. Effect of plasma nitriding on mechanical and tribological properties of 42CrMo4 steel. ECS Trans. 2016;74:231-8. http:// dx.doi.org/10.1149/07401.0231ecst.

47. Dutrey L, De Las Heras E, Svoboda HG, Corengia PA. Mechanical properties of layers obtained by DC-pulsed plasma nitriding on a low-alloy steel (AISI 4140). Plasma Process Polym. 2009;6:S314-20. http://dx.doi.org/10.1002/ppap.200932404.

48. Kwietniewski C, Fontana W, Moraes C, Rocha AS, Hirsch T, Reguly A. Nitrided layer embrittlement due to edge effect on duplex treated AISI M2 high-speed steel. Surf Coat Tech. 2004;179:2732. http://dx.doi.org/10.1016/S0257-8972(03)00795-3.

49. Noronha LC, Castro VV, Ludwig GA, Schroeder RM, Malfatti CF. Ti-Cp: eletrochemical behaviour under slurry erosion wear. J Bio Tribo Corros. 2021;7:8. http://dx.doi.org/10.1007/ s40735-020-00442-y. 